\title{
Pharmacological Discrimination of N-Type from L-Type Calcium Current and Its Selective Modulation by Transmitters
}

\author{
Daniel H. Cox and Kathleen Dunlap \\ Physiology Department and Program in Neuroscience, Tufts University School of Medicine, Boston, Massachusetts 02111
}

\begin{abstract}
GABA and norepinephrine inhibit high voltage-activated calcium current in chick sensory neurons. Using specific pharmacological tools, we have dissected this current into two components: the major one is $\omega$-conotoxin sensitive and dihydropyridine resistant ( $\mathrm{N}$-type) while the minor one is dihydropyridine sensitive and $\omega$-conotoxin resistant (L-type). The ability to selectively eliminate these two components has allowed us to determine whether the transmitters target the same or different channel types. Both GABA and norepinephrine modulate the $\mathrm{N}$-type component as evidenced by their lack of effect on (1) $\omega$-conotoxin-resistant current and (2) pure L-type tail current, prolonged by a dihydropyridine calcium channel agonist. This simple pharmacological profile will allow future tests of the significance of the two channel types in regulating sensory neuron functions.
\end{abstract}

In the past decade, research on voltage-dependent calcium channels has demonstrated multiple channel types, differing from one another biophysically, biochemically, and pharmacologically (Swandulla et al., 1991). Considering the wide variety of cellular functions controlled by the voltage-dependent influx of calcium ions across plasma membranes, it is possible that calcium channel types with unique functional properties have evolved as a means of controlling particular cellular functionsone type for altering firing threshold, for example, and another for triggering muscle contraction. In addition to playing different functional roles, calcium channel subtypes are likely to serve as differential targets for the action of both exogenous signals (such as hormones or neurotransmitters) and endogenous signals (such as GTP-binding proteins, cyclic nucleotides, and kinases).

Studying the roles of the different calcium channel subtypes and their modulators in cellular function has been experimentally problematic due, in large part, to the absence of specific pharmacological tools that can selectively block one or another channel type. Antagonists of high voltage-activated (HVA) calcium channels have been particularly wanting. Original reports of multiple HVA calcium channel subtypes suggested that two types ( $\mathrm{L}$ and $\mathrm{N}$ ) could be discriminated in dorsal root ganglion neurons on the basis of their inactivation kinetics as well as

\footnotetext{
Received Aug. 1, 1991; revised Oct. 2, 1991; accepted Oct. 18, 1991.

We thank Drs. W. Gruner and T. J. Turner for critical comments on the manuscript. The work was supported by PHS Grant NS-16483 and The McKnight Foundation.

Correspondence should be addressed to Kathleen Dunlap, Physiology Department, Tufts University School of Medicine, 136 Harrison Avenue, Boston, MA 02111.

Copyright (C) 1992 Society for Neuroscience $0270-6474 / 92 / 120906-09 \$ 05.00 / 0$
}

their pharmacology (Nowycky et al., 1985a; Fox et al., 1987a,b). Subsequent investigations, however, suggest (1) that macroscopic $\mathrm{L}$ - and $\mathrm{N}$-type calcium currents in many cells cannot be well separated kinetically (Hirning et al., 1988; Aosaki and Kasai, 1989; Plummer et al., 1989; Carbone et al., 1990); (2) that dihydropyridines (DHPs), although selective for L-type channels, exhibit voltage-dependent properties that limit their usefulness for studies of multicomponent HVA calcium currents (Sanguinctti and Kass, 1984; Sanguinetti et al., 1986; Rane et al., 1987); and (3) that subtypes of DHP-resistant current can be discriminated (Aosaki and Kasai, 1989; Plummer et al., 1989; Regan et al., 1991).

$\omega$-Conotoxin GVIA ( $\omega-\mathrm{CgTx})$, a peptide toxin from the snail Conus geographus (Olivera et al., 1985), is likely to be a potent, highly selective blocker of one type of HVA current (N-type). Although early experiments, based on kinetic separation of Land $\mathrm{N}$-type current, concluded that both types in chick dorsal root ganglion neurons were blocked irreversibly by the toxin (McClesky et al., 1987; Fox et al., 1987a), recent studies of chick dorsal root ganglion neurons (Aosaki and Kasai, 1989), rat superior cervical ganglion (SCG) neurons and pheochromocytoma (PC12) cells (Plummer et al., 1989) indicate that L-type current is not a target for irreversible toxin action.

In the work reported here, we have taken advantage of the two selective pharmacological agents, DHPs and $\omega-\mathrm{CgTx}$, to characterize the HVA calcium currents present in embryonic chick dorsal root ganglion neurons in vitro. Such characterization has allowed us to determine whether two transmitters [norepinephrine (NE) and GABA] that modulate the HVA current in these cells target the same or different channel types. Considering that both HVA calcium current and neurotransmitters play significant roles in the regulation of neurosecretion from sensory (Holz et al., 1988, 1989) and sympathetic (Perney et al., 1986; Hirning et al., 1988) neurons, results of this study are important for understanding the mechanisms involved in synaptic transmission between sensory neurons and their targets in the spinal cord.

\section{Materials and Methods}

Culture. Dorsal root ganglia were dissected from 11-12-d-old chicken embryos and grown in dissociated cell culture using previously described methods (Holz et al., 1988). The neurons were studied between days 0 and 6 in vitro.

Electrical recording. Standard tight-seal, whole-cell recording techniques were employed to study HVA calcium current from the cell bodies of the neurons (Hamill et al., 1981). A List EPC-7 patch-clamp amplifier was used for these recordings. Capacitive transients were routinely cancelled using the EPC-7's cancellation circuitry, and series resistance (typically $3.5 \mathrm{M} \Omega$ ) was compensated to about $70 \%$. Current traces were digitized at $10 \mathrm{kHz}$, stored, and analyzed on an Atari Mega 
4 ST computer using data acquisition and analysis software from Instrutech Corporation (Elmont, NY). Linear components of capacitive and leak current were subtracted from all traces before analysis using a standard $\mathrm{P} / 4$ protocol starting from a holding potential of $-100 \mathrm{mV}$. For experiments in which the time course of tail current decay was studied, records were digitized at $10 \mathrm{kHz}$ and were not filtered further (see Figs. $3 A, B ; 5 A, B$ ). In all other experiments, displayed records were filtered to $1 \mathrm{kHz}$. Unless otherwise specified, during an experiment, voltage steps were applied to the test cell every $10 \mathrm{sec}$. External solutions contained (in mM) $\mathrm{NaCl}, 150 ; \mathrm{CaCl}_{2}, 1 ; \mathrm{MgCl}_{2}, 0.8$; tetraethylammonium chloride (TEA), 10; HEPES, 25; and glucose, 5. Tetrodotoxin $(0.3$ $\mu \mathrm{M})$ was added to all solutions. In certain indicated experiments, $40 \mathrm{~mm}$ TEA and $100 \mu \mathrm{M}$ 4-aminopyridine were also added to the external solution (replacing $\mathrm{NaCl}$ ) to suppress a small amount of contaminating outward current. Patch pipettes were made from Fisherbrand glass microhematocrit capillary tubes (wall thickness, $1.1-1.2 \mathrm{~mm}$ ) and filled with a solution containing (in $\mathrm{mM}$ ) $\mathrm{CsCl}, 150$; HEPES, 10; 1,2-bis(2aminophenoxy)ethane $N, N, N^{\prime} \mathrm{N}^{\prime}$-tetra-acetic acid (BAPTA), 5 ; and $\mathrm{Mg}$ ATP, 5. Pipette resistances prior to forming high-resistance seals ranged from 1.6 to $2.3 \mathrm{M} \Omega$.

During the first $24 \mathrm{hr}$, the cells extended only short processes and excellent spatial control of voltage could be achieved. With time in culture, however, a slow component to the tail current could be observed in some cells, which likely represents a slow charging of the process membrane. Tail current experiments reported were performed on cells in which this slow component was minimal.

Solutions/chemicals. (+)-(S)-202-791 was a generous gift of Dr. Robert Hof, SANDOZ AG Preclinical Research (Basel, Switzerland). Nimodipine was à generous gift of Dr. Scriabine, Miles Pharmaceuticals. These dihydropyridines were dissolved in $95 \%$ ethanol and stored as $10 \mathrm{~mm}$ stock solutions. For experiments, they were diluted to $1-5 \mu \mathrm{M}$ as indicated in extracellular recording solution. $\omega$-CgTx GVIA was obtained from Pennisula Laboratories, stored as a stock solution of $1 \mathrm{~mm}$ in distilled water, and diluted to $9 \mu \mathrm{M}$ in external recording solution on the day of the experiment. Similarly, $10 \mathrm{~mm}$ stock solutions of GABA, bicuculline methiodide, and NE were prepared in distilled water and diluted to their final experimental concentrations of $100 \mu \mathrm{M}$ (GABA and bicuculline) and 10-50 $\mu \mathrm{M}(\mathrm{NE})$, in external recording solution. Drugs and transmitters were applied using puffer pipettes with tip diameters approximately 3-5 $\mu \mathrm{m}$ as previously described (Rane and Dunlap, 1990).

\section{Results}

$\omega$-CgTx selectively blocks a DHP-resistant calcium current

In our studies, we found few cells that exhibited low voltageactivated calcium current when measured from a holding potential of $-80 \mathrm{mV}$. Those cells that did were excluded from our study so as to simplify the measurement of the peak of the HVA current. The efficacy of $\omega-\mathrm{CgTx}$ on the HVA current in dorsal root ganglion neurons in vitro varied with age of the cultured neurons. Acutely dissociated cells (or cells tested within $1 \mathrm{~d}$ of plating) exhibited virtually no $\omega$-CgTx-resistant current (i.e., 9 $\mu \mathrm{M}$ toxin blocked $100 \%$ of the HVA calcium current) (Fig. $1 \mathrm{~A}$ ). As first described by Aosaki and Kasai (1989), these pure $\omega-\mathrm{CgTx}-$ sensitive currents activated following step depolarizations to potentials more positive than $-30 \mathrm{mV}$, reached a maximum at $0 \mathrm{mV}$, and reversed near $55 \mathrm{mV}$ (Fig. 1C). Such HVA current inactivated as a function of the holding potential. In $80 \%$ of the cells studied within $1 \mathrm{~d}$ of plating, half-maximal inactivation occurred at $-53 \mathrm{mV}(n=15$; Fig. $1 B$ ); in these cells, a $70 \%$ reduction of the peak current (measured at $0 \mathrm{mV}$ ) was produced when the holding potential was changed from -80 to $-40 \mathrm{mV}$. The other $20 \%$ of the cells studied exhibited a less pronounced dependence on holding potential. In these, only a $30 \%$ reduction in peak current was produced following depolarization of the holding potential from -80 to $-40 \mathrm{mV}$. An example of such a holding potential-resistant current (that is $\omega-\mathrm{CgTx}$ sensitive) is shown in Figure 2 for a cell that had been $5 \mathrm{~d}$ in culture.

The inactivation rate of the $\omega-\mathrm{CgTx}$-sensitive current during a test pulse was also variable and dependent upon the holding potential from which an activating test pulse was given. During a $150 \mathrm{msec}$ depolarization to $0 \mathrm{mV}$ from a holding potential of $-60 \mathrm{mV}$, $\omega$-CgTx-sensitive current decayed steadily and incompletely to an average $50 \pm 7 \%$ (mean $\pm \mathrm{SD} ; n=12$ ) of its peak value (Fig. $1 A$, trace 1 ). The extent of decay in this series of experiments ranged between $40 \%$ and $80 \%$. In general, the currents that displayed the more prominant inactivation during a test pulse were also more sensitive to inactivation with depolarized holding potentials. When the neurons were held at $-40 \mathrm{mV}$, the peak current during the test pulse was not only reduced, as discussed, but the $\omega-\mathrm{CgTx}$-sensitive current decayed approximately five times more slowly ( $72 \pm 9 \%$ of peak by 150 msec; $n=12$ ) than currents evoked by depolarizations from $-60 \mathrm{mV}$ holding potentials. Observed on this limited time scale, $\omega-\mathrm{CgTx}$-sensitive calcium current elicited from a $-40 \mathrm{mV}$ holding potential often appeared to be noninactivating (Fig. $1 \mathrm{~A}$, trace 2). Interestingly, voltage steps from $-60 \mathrm{mV}$ to $+80 \mathrm{mV}$ elicited outward currents that could be blocked by $\omega-\mathrm{CgTx}$ and presumably represent cesium ions moving out of the cell through $\omega-\mathrm{CgTx}$ sensitive calcium channels (Fenwick et al., 1982; Lee and Tsien, 1982). This outward current did not inactivate at all over the course of a $150 \mathrm{msec}$ voltage step ( $n=5$; Fig. $1 D$, trace 2$)$, suggesting that the inactivation of $\omega-\mathrm{CgTx}$-sensitive inward current during a test pulse may represent a calcium-dependent rather than a voltage-dependent process. Thus, variability in the rate of this process may be due to some variability in the efficacy of intracellular calcium buffering.

Over time in vitro, the proportion of $\omega-\mathrm{CgTx}$-resistant current increased. For neurons between 3 and $6 \mathrm{~d}$ in culture, $60 \mathrm{sec}$ applications of the toxin blocked $86 \pm 9 \%(n=44)$ of the HVA calcium current activated by step depolarizations to 0 or +10 $\mathrm{mV}$ from a holding potential of $-60 \mathrm{mV}$ (Fig. 2). The percentage inhibition produced by $\omega-\mathrm{CgTx}$ was largely independent of holding potentials between -80 and $-40 \mathrm{mV}$ as shown in Figure $2 C$.

At all times studied, the portion of HVA calcium current inhibited by $\omega-\mathrm{CgTx}$ was larger than that previously attributed to any one dorsal root ganglion neuron calcium current type when defined by whole-cell current inactivation kinetics or holding potential dependence (Nowycky et al., 1985a; Fox et al., $1987 \mathrm{a}, \mathrm{b})$. Based on a classification of HVA currents in which the long-lasting $(\mathrm{L})$ and inactivating $(\mathrm{N})$ components represent distinct current types, our results with $\omega$-CgTx would suggest that both $\mathrm{N}$ - and I-type currents are blocked by the peptide, as McClesky et al. (1987) reported.

In order to directly test whether $\omega-\mathrm{CgTx}$ blocks L current in chick dorsal root ganglion neurons, we employed the DHP (+)(S)-202-791. Like Bay K 8644, this pure calcium channel agonist shifts the voltage dependence of activation of L-type calcium channels and prolongs their apparent mean channel open time (Hess et al., 1984; Nowycky et al., 1985b; Plummer et al., 1989). This increase in mean channel open time results in a prolongation of macroscopic tail current deactivation kinetics (Plummer et al., 1989; Regan et al., 1991). We have investigated the ability of $\omega-\mathrm{CgTx}$ to reduce this slow, pure L-type tail current. Figure 3 shows an example of one such experiment performed on a cell with a larger-than-average $\omega$-CgTx-resistant component of calcium current. Prior to the application of $(+)-(S)-202-$ $791(2 \mu \mathrm{M})$, the time course for tail current deactivation was relatively fast, decaying to $37 \%$ of its peak in approximately $600 \mu \mathrm{sec}$ (Fig. 3A, trace 1). Application of the DHP agonist 

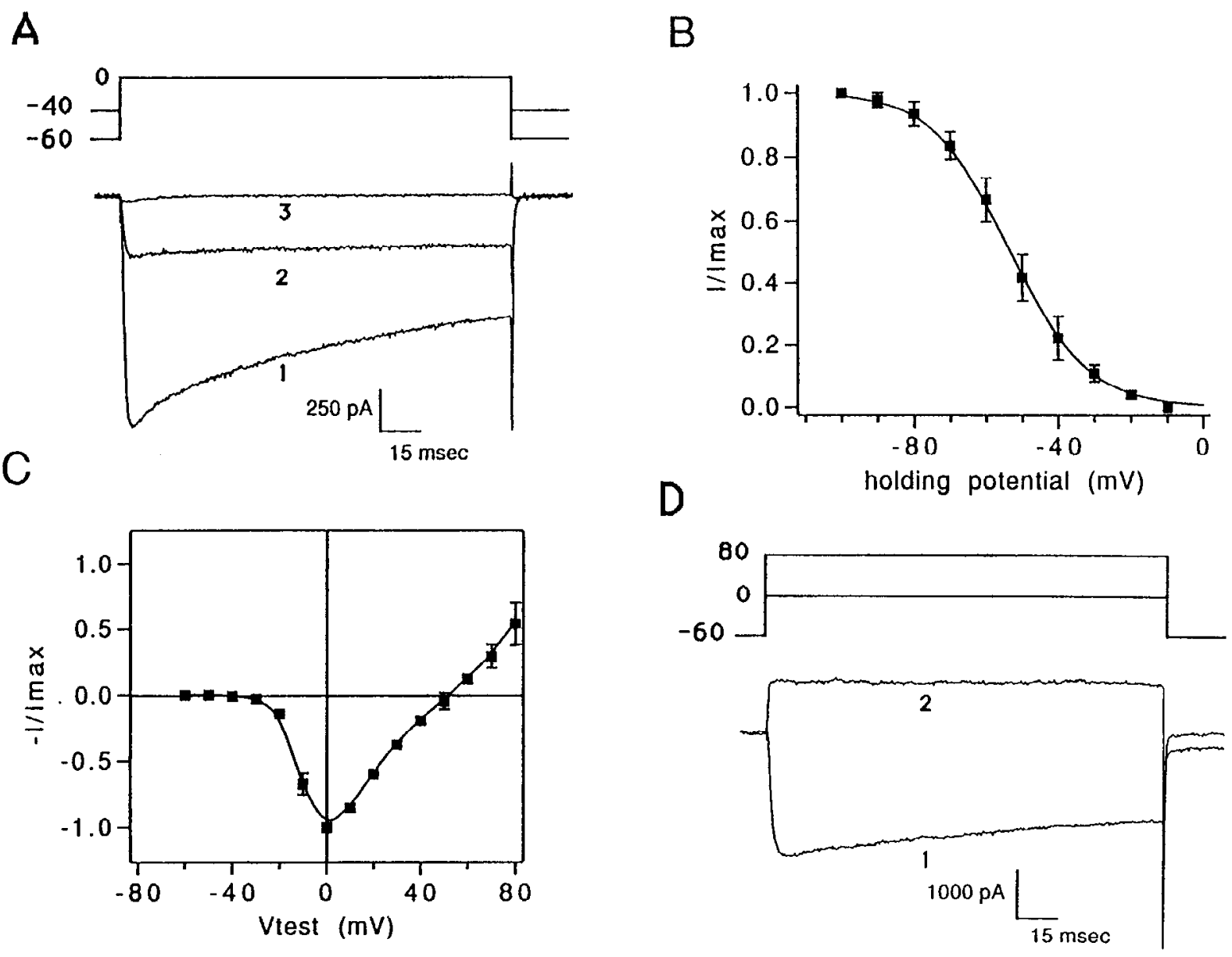

Figure 1. Properties of $\omega-\mathrm{CgTx}$-sensitive calcium current measured in chick dorsal root ganglion neurons prior to $1 \mathrm{~d}$ in vitro. $A$, Whole-cell calcium currents elicited with $150 \mathrm{msec}$ voltage steps from holding potentials of $-60 \mathrm{mV}$ (trace I) or $-40 \mathrm{mV}$ (trace 2) to a test potential of 0 $\mathrm{mV}$. Trace 3 shows current measured after the application of $9 \mu_{\mathrm{M}} \omega$-CgTx (holding potential, $-80 \mathrm{mV}$ ). $B$, Steady-state inactivation curve for $\omega$-CgTx-sensitive current. Data points represent the average normalized peak currents measured from five cells. The data are fit with a Boltzmann relation, $I / I_{\max }=1 /\left(1+\exp \left\{\left(V-V_{1 / 2}\right) / r\right\}\right.$ ) (solid line) with $V_{1 / 2}=-53 \mathrm{mV}$ and $r=10$. C, Current-voltage relationship for normalized peak $\omega$-CgTx-sensitive calcium current. Data points represent the average of four measurements. $D$, Inward and outward current flowing through $\omega$-CgTx-sensitive channels. Currents were elicited with $150 \mathrm{msec}$ voltage steps from $-60 \mathrm{mV}$ to either $0 \mathrm{mV}$ (trace 1$)$ or $80 \mathrm{mV}$ (trace 2). Any residual currents measured in the presence of $\omega$-CgTx were subtracted from the control currents to yield $\omega$-CgTx-sensitive current. Traces in $A$ and $B$ were recorded from cells bathed in saline containing $50 \mathrm{mM}$ TEA and $100 \mu \mathrm{M}$ 4-aminopyridine.

resulted in the appearance of a slow component to the tail current with an average $(n=12)$ time constant of $4 \mathrm{msec}$ (Fig. $3 B$, trace 2). At times later than $\sim 3 \mathrm{msec}$ (when the fast component has decayed to near zero; Fig. $3 B$, arrow), the tail current represents a pure L-type current. Upon application of $\omega$-CgTx to this cell, the test pulse current was reduced $45 \%$ while the ( + (S)-202-791-sensitive component of tail current was virtually unaffected by the toxin (Fig. 3B, trace 3). Similar results have been described in rat SCG (Plummer et al., 1989) and dorsal root ganglion (Regan et al., 1991) ncurons.

The apparent difference between traces 2 and 3 in Figure $3 B$ at early times results from changes in the rapidly deactivating, $\omega$-CgTx-sensitive component of tail current. Currents were fit beginning $3.0 \mathrm{msec}$ after repolarization in order to eliminate interference by changes in this rapidly deactivating current. The extrapolated amplitudes of these fits were used as an index of L-type calcium current inhibition by $\omega$-CgTx. In four cells selected for study because they showed relatively large toxin-resistant currents, we found $\omega-\mathrm{CgTx}$ blocked an average of $\mathbf{5 0 . 5}$ $\pm 7.3 \%$ of the test pulse current elicited with a voltage pulse from $-60 \mathrm{mV}$ to $10 \mathrm{mV}$. In contrast, the inhibitory effect on the $(+)-(S)-202-791$-prolonged tail component was $0.35 \pm 9.7 \%$. Thus, $\omega-\mathrm{CgTx}$ appears to be selective for a DHP-resistant current.

\section{$\omega$-CgTx-resistant current is highly sensitive to DHPs}

Unlike Aosaki and Kasai (1989) and Plummer et al. (1989), we did not observe, over a $10 \mathrm{~min}$ period, any component of HVA current that recovered from $\omega-\mathrm{CgTx}$ block $(n=10$; Fig. $3 C)$. Wc were thus able to study $\omega$-CgTx-resistant current in isolation after a single application of the toxin. Applying (+)-(S)-202791 to cells that had previously been treated with $\omega$-CgTx greatly enhanced $(172 \pm 81 \% ; n=7)$ the residual current recorded following test pulses to $-20 \mathrm{mV}$ (Fig. $4 A$, traces 1 and 2). This enhanced current was unaffected by the reapplication of $\omega$-CgTx (Fig. 4A, trace 3). Furthermore, when elicited from a holding potential of $-40 \mathrm{mV}$, the $\omega$-CgTx-resistant current was blocked completely by the DHP antagonist nimodipine ( $5 \mu \mathrm{M} ; n=9$; Fig. $4 B$, trace 4 ). On the basis of these results, we conclude that there are two types of pharmacologically distinct HVA calcium 

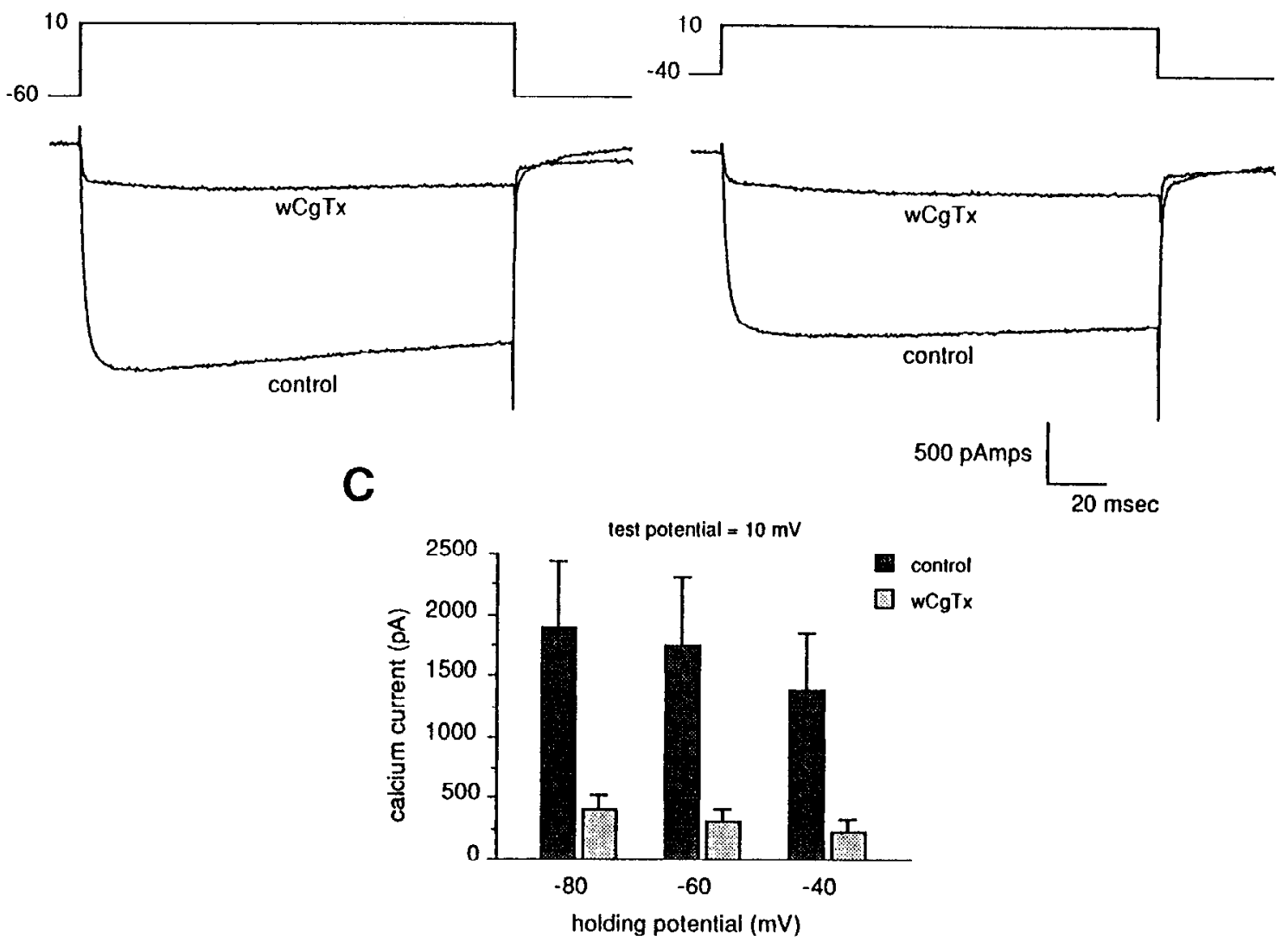

$20 \mathrm{msec}$ Figure 2. $\omega$-CgTx sensitivity of calcium current recorded from chick dorsal root ganglion neurons after $3-6 \mathrm{~d}$ in vitro. Whole-cell calcium currents
were measured from holding potentials of $-60 \mathrm{mV}(A)$ and $-40 \mathrm{mV}(B)$ before and after the application of $9 \mu \mathrm{M} \omega$-CgTx. C, Histogram illustrating the average amplitudes $(n=6)$ of calcium currents in control (dark shading) and $\omega$-CgTx-treated (light shading) cells. Currents were evoked by depolarizing pulses to $10 \mathrm{mV}$ from holding potentials of $-40,-60$, and $-80 \mathrm{mV}$.

current in chick dorsal root ganglion neurons: L-type, which is sensitive to DHPs and resistant to $\omega$-CgTx, and N-type, which is irreversibly blocked by $\omega$-CgTx and resistant to DHPs. We define here N-type current solely on the basis of these pharmacological criteria and by doing so do not mean to attribute to this current component any specific kinetic characteristics. In contrast to other studies on peripheral and central neurons (Aosaki and Kasai, 1989; Plummer et al., 1989; Regan et al., 1991), no component of HVA current in any of the dorsal root ganglion neurons tested was found to be resistant to both $\omega$-CgTx and DHPs.

\section{Neurotransmitters modulate the $\omega$-CgTX-sensitive current}

Superfusion of dorsal root ganglion neurons with $100 \mu \mathrm{M}$ GABA substantially inhibits whole-cell calcium current. This GABAinduced inhibition is characterized by a slowing of the activation kinetics (Fig. 5C, trace 2; Grassi and Lux, 1989). On average, calcium current was inhibited $37 \pm 5 \%(n=5)$ when measured $15 \mathrm{msec}$ after the start of a depolarizing test pulse to $0 \mathrm{mV}$ and $21 \pm 5 \%$ when measured at $150 \mathrm{msec}$ (Fig. $5 \mathrm{C}$ ). The ability of GABA to inhibit a larger percentage of calcium current than that carried by $\omega$-CgTx-resistant channels $(\sim 14 \%)$ strongly suggests that GABA inhibits, at least in part, N-type channels. It is possible, however, that GABA also modulates L-type current.
In order to investigate this, we examined the ability of GABA to inhibit the $(+)-(S)$-202-791-prolonged component of calcium tail current observed upon repolarization to $-60 \mathrm{mV}$. Figure $5 A$ shows the results of one such experiment. Calcium current recorded following a $10 \mathrm{msec}$ depolarization to $10 \mathrm{mV}$ was inhibited $35 \%$ by $100 \mu \mathrm{M}$ GABA; however, GABA had no significant inhibitory effect $(<1 \%)$ on the slowly decaying component of tail current produced by superfusion of this cell with $(+)-(S)-202-791$ (Fig. 5A, trace 3). Figure 5B compares the $(+)-$ (S)-202-791-sensitive component of calcium tail current before and after application of GABA. This tail current component was fit with a single exponential in the manner described for the experiment of Figure 3 (see above). Any change in L-type current magnitude was gauged by the difference between the amplitudes of the current fits before and after GABA treatment. In seven experiments of this type, GABA inhibited the test pulse current an average of $30 \pm 7 \%$ but produced no significant reduction in the DHP-sensitive tail current $(6 \pm 6 \%)$.

To control for the possibility that $(+)-(S)-202-791$ protects L-type channels from being modulated by GABA, we examined the ability of the transmitter to inhibit whole-cell calcium current before and after block of N-type current with $\omega$ - $\mathrm{CgTx}$, in the absence of the DHP agonist. Studying cells that showed large GABA-induced current inhibitions prior to $\omega$-CgTx application, 


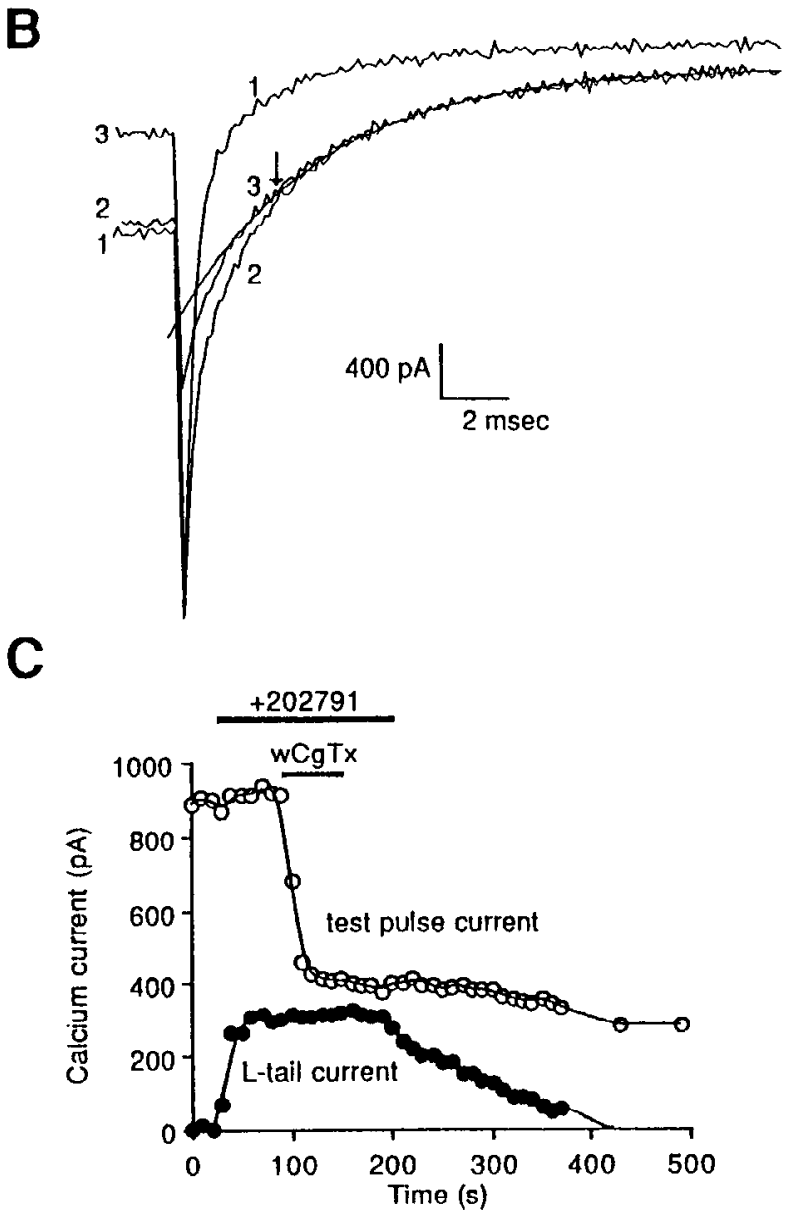

Figure 3. $\omega$-CgTx does not block L-type calcium current in chick dorsal root ganglion neurons. $A$, Whole-cell calcium currents measured during a $20 \mathrm{msec}$ voltage step from $-60 \mathrm{mV}$ to $10 \mathrm{mV}$ and after repolarization to $-60 \mathrm{mV}$ under the following conditions: control (trace 1 ), during application of $2 \mu \mathrm{M}(+)-(S)-202-791$ (trace 2), and during coapplication of both (+)-(S)-202-791 and $9 \mu \mathrm{M} \omega-\mathrm{CgTx}($ trace 3). B, Tail currents from the experiment in $A$ viewed on an expanded time scale. Numbered traces correspond to the same conditions as in $A$. Traces 2 and 3 are fit at points later than $3 \mathrm{msec}$ after repolarization (arrow) to an exponential function with a time constant of $3.9 \mathrm{msec}$ and an initial amplitude of $-2140 \mathrm{pA}$ (smooth curve). $C$, Time courses for the effects of $(+)-(S)-202-791$ and $\omega-\mathrm{CgTx}$ on the amplitude of test pulse current measured at the end of a 20 msec voltage step (open circles) and on the tail current amplitude measured $3 \mathrm{msec}$ after repolarization (solid circles). Data in $C$ are from a different cell.

A
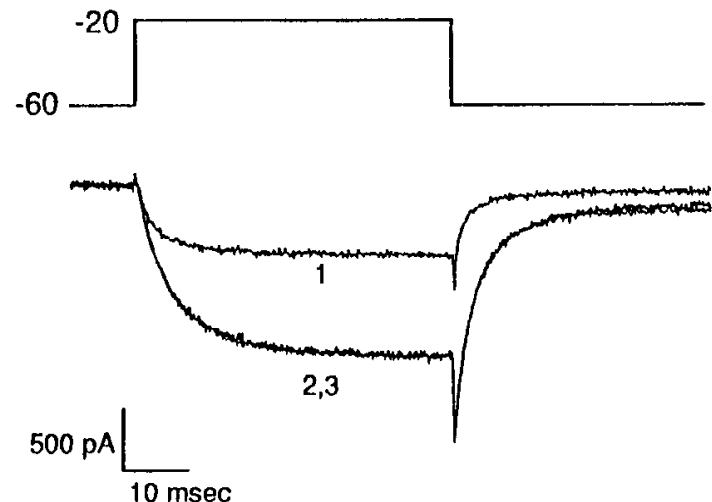

B
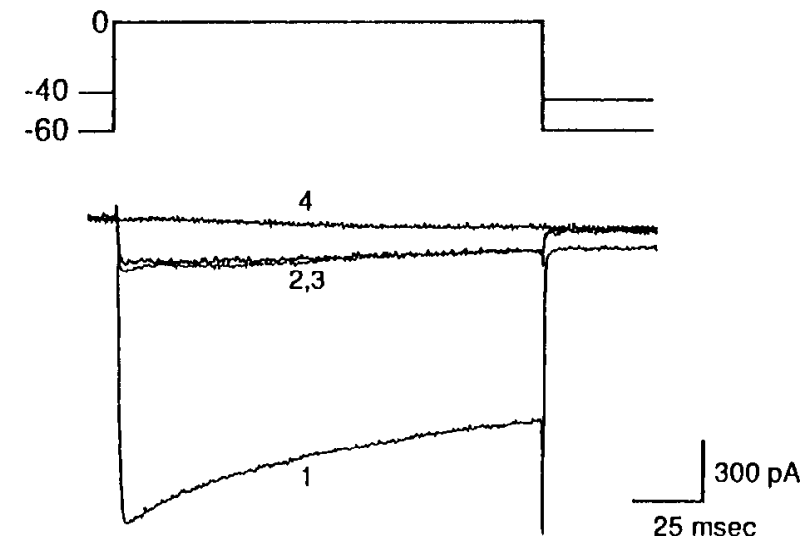

Figure 4. $\omega$-CgTx-resistant calcium current is sensitive to DHPs. $A$, Whole-cell calcium current measured after an initial application of $9 \mu \mathrm{M}$ $\omega-\mathrm{CgTx}($ trace 1$)$, during subsequent application of $(+)-(S)-202-791$ (trace 2$)$, and during reapplication of $\omega-\mathrm{CgTx}$ in the presence of $(+)-(S)-202-$ 791 (trace 3). $B$, Whole-cell calcium currents measured following $150 \mathrm{msec}$ voltage steps to $0 \mathrm{mV}$ under the following conditions: from a holding potential of $-60 \mathrm{mV}$ (trace 1), from a holding potential of $-60 \mathrm{mV}$ after $9 \mu \mathrm{M} \omega-\mathrm{CgTx}$ was applied to the cell (trace 2), from a holding potential of $-40 \mathrm{mV}$ after $\omega$-CgTx application (trace 3), and from a holding potential of $-40 \mathrm{mV}$ after $\omega$-CgTx application and then subsequent application of $5 \mu \mathrm{M}$ nimodipine (trace 4). In $B$, the solution bathing the cell contained $50 \mathrm{mM}$ TEA and 100 $\mu \mathrm{M}$ 4-aminopyridine. 


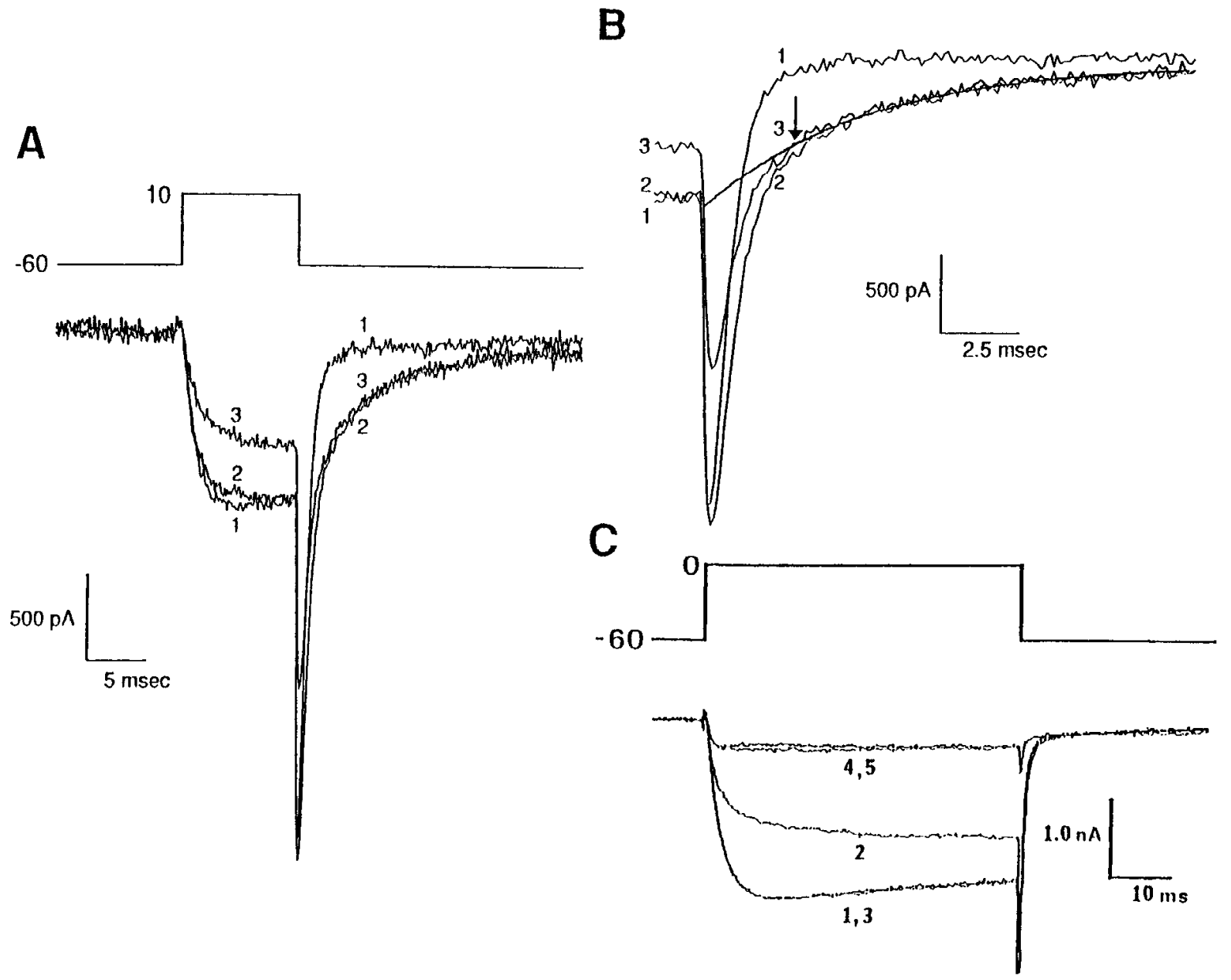

Figure 5. GABA inhibits an $\omega$-CgTx-sensitive but not a DHP-sensitive calcium current in chick dorsal root ganglion neurons. $A$, Whole-cell calcium currents measured during a $10 \mathrm{msec}$ voltage step from $-60 \mathrm{mV}$ to $10 \mathrm{mV}$ and after repolarization to $-60 \mathrm{mV}$ under the following conditions: control (trace 1), during application of $2 \mu \mathrm{M}(+)-(S)-202-791$ (trace 2$)$, and during coapplication of both $(+)-(S)-202-791$ and $100 \mu \mathrm{M}$ GABA plus $100 \mu \mathrm{M}$ bicuculline, to block $\mathrm{GABA}_{\mathrm{A}}$-induced increases in chloride permeability (trace 3 ). $B$, Tail currents from the experiment in $A$ viewed on an expanded time scale. Numbered traces correspond to the same conditions as in $A$. Traces 2 and 3 are fit at points later than 3 msec after repolarization (arrow) to an exponential function (smooth line) with a time constant of $6.9 \mathrm{msec}$ and an initial amplitude of $940 \mathrm{pA}$. $C$, Wholecell calcium currents measured during $50 \mathrm{msec}$ voltage steps to $0 \mathrm{mV}$ from $-60 \mathrm{mV}$ under the following conditions: control (trace 1 ), during superfusion of the test cell with $100 \mu \mathrm{M}$ GABA (trace 2), after recovery from GABA application (trace 3), after application of $9 \mu \mathrm{M} \omega$-CgTx (trace 4 ), and during subsequent application of GABA (trace 5). All solutions in $C$ contained $100 \mu \mathrm{M}$ bicuculline, 50 mMTEA, and $100 \mu \mathrm{M} 4-$ aminopyridine.

we found no significant inhibition of $\omega$-CgTx-resistant calcium current by the transmitter (Fig. $5 C$ ). In five such experiments, GABA inhibited HVA calcium current by $37 \pm 5 \%$ (measured at $15 \mathrm{msec}$ ) before $\omega-\mathrm{CgTx}$ application, while no effect was observed on $\omega$-CgTx-resistant current ( $<2 \%$ inhibition). In all cases, the amplitude of GABA-sensitive calcium current was substantially larger than the $\omega-\mathrm{CgTx}$-resistant current in these cells. It is therefore clear from the above experiments that GABA inhibits an $\omega$ - $\mathrm{CgTx}$-sensitive, DHP-resistant component of calcium current, defined as $\mathrm{N}$-type.

We have also examined the ability of NE to inhibit dorsal root ganglion neuron whole-cell calcium current before and after the test cell was treated with $9 \mu \mathrm{M} \omega$-CgTx (Fig. 6). As with GABA, a saturating dose of NE (10-50 $\mu \mathrm{M})$ inhibited a large percentage of calcium current $(22 \% \pm 7 \% ; n=12$; Fig. 6 , traces 1 and 2) before $\omega$-CgTx treatment, but had no effect on the residual inward current after $\omega$-CgTx treatment ( $<1 \%$; Fig. 6, traces 4 and 5). Thus, like GABA, NE appears to inhibit exclusively $\mathrm{N}$-type current.

\section{Differences in NE- and GABA-induced inhibition of calcium current}

Inhibition of HVA calcium current by GABA is characterized by an invariant and prominent slowing of the activation kinetics (Fig. 5C). This effect is clearly seen even with short-duration $(10 \mathrm{msec})$ depolarizations and is mimicked by the $\mathrm{GABA}_{\mathrm{B}}$ receptor agonist baclofen (data not shown). Upon depolarization to $0 \mathrm{mV}$, currents taken before GABA application reach a peak within $20 \mathrm{msec}$, while after application of $100 \mu \mathrm{M} \mathrm{GABA}$ calcium currents often do not reach a peak by the end of a $50 \mathrm{msec}$ voltage step. In contrast, the inhibition produced by NE is most often not accompanied by such a kinetic change (Fig. 6). In these cells, the NE-resistant and NE-sensitive components of the current are kinetically similar (Dunlap and Fischbach, 1981; Forscher and Oxford, 1985). A small percentage of dorsal root ganglion neurons, however, do exhibit an effect of NE on the activation kinetics that differs from the slowing produced by GABA. In these cells, the initial activation rate remains little 

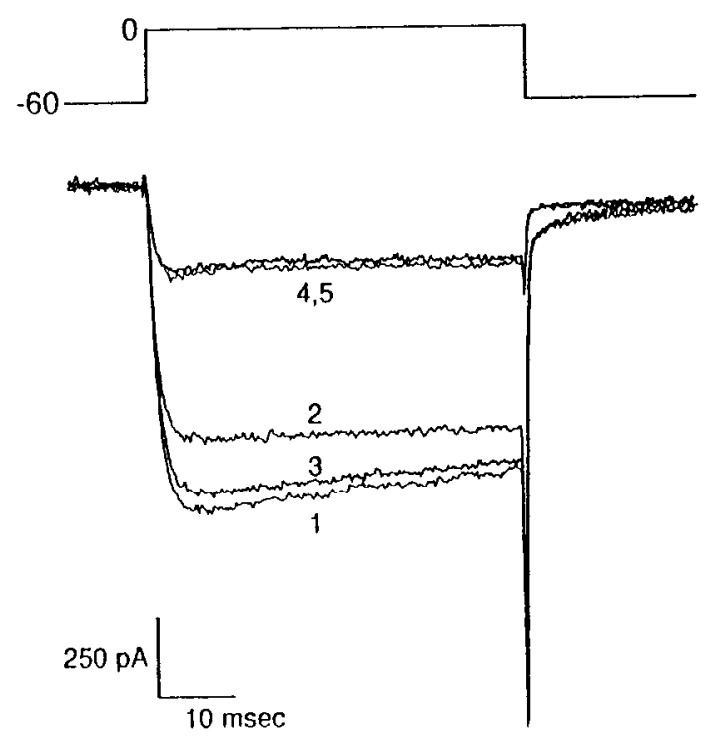

Figure 6. NE also inhibits an $\omega-\mathrm{CgTx}$-sensitive calcium current in chick dorsal root ganglion neurons. Whole-cell calcium currents measured during $50 \mathrm{msec}$ voltage steps to $0 \mathrm{mV}$ from $60 \mathrm{mV}$ under the following conditions: control (trace 1), during superfusion of the test cell with $10 \mu \mathrm{M}$ NE (trace 2), after recovery from NE application (trace 3), after application of $9 \mu \mathrm{M} \omega-\mathrm{CgTx}$ (trace 4), and during subsequent application of NE (trace 5). All solutions contained $50 \mathrm{~mm}$ TEA and $100 \mu \mathrm{M}$ 4-aminopyridine.

affected by the transmitter but an additional, slower component to the activation can be observed with long ( $>100 \mathrm{msec}$ ) pulses. The significance of such differences in transmitter action is unclear at present.

\section{Discussion}

Pharmacological separation of calcium current subtypes

Using the calcium channel blocker $\omega-\mathrm{CgTx}$ and two DHPs$(+)-(S)-202-791$, which enhances L-type Ca channel activity, and nimodipine, which inhibits these same channcls-we have discerned only two pharmacologically separable components of HVA calcium current present in dorsal root ganglion neurons of embryonic chick. The $\omega$-CgTx-sensitive component makes up the vast majority of the HVA current, confirming results of others for chick dorsal root ganglion neurons (Kasai et al., 1987; Aosaki and Kasai, 1989) and rat SCG neurons and PC12 cells (Plummer et al., 1989). Our studies, however, do not demonstrate the reversible component to the $\omega$-CgTx-sensitive HVA current reported by these investigators. Additionally, we have found that the component of calcium current in chick dorsal root ganglion neurons that is insensitive to $\omega$-CgTx is completely blocked by nimodipine, indicating an L-type current. In contrast to other tissues, no HVA calcium current that was resistant to both DHPs and $\omega$-CgTx was observed. Such a resistant component makes up $>90 \%$ of the HVA current in cerebellar Purkinje neurons, $50 \%$ in hippocampal CA1 neurons (Regan et al., 1991 ), $40 \%$ in PC12 cells, and 10\% in SCG neurons (Plummer et al., 1989).

We report that $\omega$-CgTx is unable to inhibit the slow component of tail current produced by $(+)-(S)-202-791$ modulation of L-type calcium current, and on this basis have concluded that $\omega$-CgTx does not inhibit L-type channels. While our experiments do not rule out the possibility that there is a component of DHP-sensitive current that is protected from the blocking effects of $\omega-\mathrm{CgTx}$ by $(+)-(S)-202-791$, we feel, for the following reasons, that if such a current exists, it must be a minor component of the total calcium current. (1) In the absence of $(+)-(S)-202-791$, $\omega$-CgTx often does not inhibit all calcium current, but rather leaves behind a current that is exquisitely sensitive to DHPs. (2) In the great majority of cells, $\omega$-CgTx blocks most of the calcium current even in the presence of $(+)-(S)-202-791$. Thus, our investigations have led us to a simple pharmacological profile of calcium current types in chick dorsal root ganglion neurons. $\mathrm{N}$-type current, which is irreversibly blocked by $\omega$-CgTx, and L-type, which is unaffected by $\omega$-CgTx but sensitive to DHPs.

\section{Kinetic separation of calcium current subtypes}

Original reports of $\mathrm{L}$ - and $\mathrm{N}$-type calcium currents in chick dorsal root ganglion neurons suggested that the two current components could be resolved by their differential inactivation kinetics and sensitivity to holding potential (Nowycky et al., 1985a; Fox et al., 1987a). As a result, conclusions of many previous studies that have relied on these kinetic distinctions to determine the pharmacological profiles and physiological significance of $\mathrm{L}$ - and $\mathrm{N}$-type calcium channels are likely to be incorrect. As a case in point, McClesky et al. (1987) and Fox et al. (1987a) interpreted the $\omega$-CgTx block of long-lasting current in dorsal root ganglion neurons as indicating a block of L-type current. Similarly, the fact that NE and GABA inhibited a longlasting component of HVA calcium current (that remained available at $-40 \mathrm{mV}$ holding potentials) prompted us to conclude that the transmitters also targeted L-type channcls (Rane et al., 1987; Holz et al., 1989). However, steady-state inactivation studies reported here for the HVA current indicate that a significant fraction of the $\omega$-CgTx-sensitive (non-L-type) component in dorsal root ganglion neurons remains at such depolarized holding potentials. Furthermore, both the $\omega-\mathrm{CgTx}-\mathrm{sen}-$ sitive and the DHP-sensitive current components inactivate only slightly during a $150 \mathrm{msec}$ pulse (when depolarized holding potentials are used) and thus exhibit similar long-lasting wave forms. Since the pharmacological agents employed in the present study ( $\omega-\mathrm{CgTx}$ and DHPs) can differentiate these kinetically similar current components, they allow us now to argue that the $\mathrm{N}$-type channel is the more likely target and that L-type calcium channels are not modulated by the two transmitters.

\section{Differences in transmitter-mediated modulation of $H V A$ calcium channels}

Although NE and GABA both appear to target the same current type, certain characteristics of the modulation differ for the two transmitters. Inhibition by GABA of HVA current in peripheral neurons is characterized by a very prominent slowing of the activation kinetics (Fig. 5; Grassi and Lux, 1989). Such effects on peripheral neurons are common to many other transmitters and peptides as well, including dopamine (Marchetti et al., 1986), somatostatin (Ikeda and Schofield, 1989), ACh (Wanke et al., 1987), adenosine (Kasai and Aosaki, 1989), and leutinizing hormone-releasing hormone (Elmslie et al., 1990). Inhibition of peripheral neuron HVA calcium current by transmitters such as NE, neuropeptide $Y$, and bradykinin, on the other hand, is most often not associated with such kinetic alterations (Dunlap and Fischbach, 1981; Forscher and Oxford, 1985; Bean, 1989; Ewald et al., 1989). Similar discrepancies have been observed on central neurons as well (Toselli et al., 1989; Sah, 1990). At present, it is unclear how such differences in transmitter action 
are brought about. Differing kinetics of activation between GABA- and NE-modulated currents in embryonic chick dorsal root ganglion neurons are unlikely to be due to different subtypes of $\omega$-CgTx-sensitive calcium channels: Swandulla and Armstrong (1988) demonstrated in acutely dissociated neurons that the deactivation kinetics of HVA calcium current are well described by a single exponential function. They argue that freshly dissociated neurons contain a single type of HVA calcium current.

All transmitters reported to inhibit HVA calcium current are thought to require the activation of GTP-binding proteins (Tsien et al., 1988; Rane and Dunlap, 1990). Experiments in which GTP- $\gamma$-S has been used to activate G-proteins in the absence of transmitter (Dolphin et al., 1988; Marchetti and Robello, 1989; Elmslie et al., 1990) demonstrate a prominent inhibition of calcium current and slowing of the activation kinetics, mimicking the action of several transmitters. In contrast to GTP- $\gamma$ $S$, which promotes the indiscriminate activation of all available G-proteins (Gilman, 1987), the transmitters are likely to exhibit some selectivity in their G-protein interactions (Hescheler et al., 1987; Ewald et al., 1989). It is possible that the slowing of HVA calcium current activation kinetics is associated with some, but not all, G-proteins, and that differences in transmitter effects on current kinetics reflect selectivity of receptor-G-protein interactions.

\section{Implications for the regulation of neurotransmitter release}

The presence of only two HVA current components blocked by selective and potent antagonists makes chick dorsal root ganglion neurons a powerful experimental system for testing the role of calcium channel subtypes in the regulation of cellular function. This new information also allows us to review past results in a new light. Holz et al. (1988) demonstrated that the electrically stimulated release of substance $P$ from cultured dorsal root ganglion neurons was eliminated by $\omega$-CgTx, suggesting that $\mathrm{N}$-type channels play a prominent role in triggering exocytosis. Significantly, the electrically evoked release was relatively resistant to blockade by the DHP antagonist nifedipine but was enhanced $45 \%$ by the DHP agonist Bay K 8644 . This indicates that the L-type calcium channel might only play a significant role in triggering peptide release under conditions in which its calcium permeability is potentiated (Miller, 1987). In contrast, substance $\mathrm{P}$ release evoked by chronic depolarization of the neurons with elevated potassium is much more sensitive to DHPs (blocked $58 \%$ by nifedipine and enhanced $115 \%$ by Bay $K$ 8644). Whether this enhanced sensitivity results from the voltage-dependent action of DHPs (Sanguinetti and Kass, 1984; Sanguinetti et al., 1986; Rane et al., 1987) or differential inactivation of N-type over L-type channels (Jones and Jacobs, 1990) remains unclear. Knowledge of the distinct pharmacological identities of these channel types, however, will now enable a determination of their relative contributions to release of peptide and classical transmitters from these neurons.

\section{References}

Aosaki N, Kasai H (1989) Characterization of two kinds of highvoltage-activated Ca-channel currents in chick sensory neurons. Differential sensitivity to dihydropyridines and $\omega$-conotoxin GVIA. Pfluegers Arch 414:150-156.

Bean BP (1989) Neurotransmitter inhibition of neuronal calcium currents by changes in channel voltage dependence. Nature 340:153156.

Carbone E, Sher E, Clementi F (1990) Ca currents in human neuroblas- toma IMR32 cells: kinetics, permeability and pharmacology. Pfluegers Arch 416:170-179.

Dolphin AC, Wootton JF, Scott RH, Trentham DR (1988) Photoactivation of intracellular guanosine triphosphate analogues reduces the amplitude and slows the kinetics of voltage-activated calcium channel currents in sensory neurones. Pfluegers Arch 411:628-636.

Dunlap K, Fischbach GD (1981) Neurotransmitters decrease the calcium conductance activated by depolarization of embryonic chick sensory neurones. J Physiol (Lond) 317:519-535.

Elmslie KS, Zhou W, Jones SW (1990) LHRH and GTP- $\gamma-S$ modify calcium current activation in bullfrog sympathetic neurons. Neuron 5:75-80.

Ewald DA, Pang I-H, Sternweis PC, Miller RJ (1989) Differential G protein-mediated coupling of neurotransmitter receptors to $\mathrm{Ca}$ channels in rat dorsal root ganglion neurons in vitro. Neuron 2:1185-1193.

Fenwick E, Marty A, Neher E (1982) Sodium and calcium channels in bovine chromaffin cells. J Physiol (Lond) 331:599-635.

Forscher P, Oxford GS (1985) Modulation of calcium channels by norepinephrine in internally dialyzed avian sensory neurons. J Gen Physiol 85:743-763.

Fox AP, Nowycky MC, Tsien RW (1987a) Kinetics and pharmacological properties distinguishing three types of calcium currents in chick sensory neurones. J Physiol (Lond) 394:149-172.

Fox AP, Nowycky MC, Tsien RW (1987b) Single-channel recordings of three types of calcium channels in chick sensory neurones. J Physiol (Lond) 394:173-200.

Gilman $\Lambda G$ (1987) $G$ proteins: transducers of receptor-generated signals. Annu Rev Biochem 56:615-649.

Grassi F, Lux HD (1989) Voltage-dependent GABA-induced modulation of calcium currents in chick sensory neurons. Neurosci Lett 105:113-119.

Hamill OP, Marty A, Neher E, Sakmann B, Sigworth FJ (1981) Improved patch-clamp techniques for high-resolution current recordings from cells and cell-free membrane patches. Pfluegers Arch 391:85100 .

Hescheler J, Rosenthal W, Trautwein W, Schultz G (1987) The GTPbinding protein $G_{o}$ regulates neuronal calcium channels. Nature 325 : $445-447$.

Hess P, Lansman JB, Tsien RW (1984) Different modes of calciumchannel gating behaviour favoured by dihydropyridine $\mathrm{Ca}$ agonists and antagonists. Nature 311:538-544.

Hirning LD, Fox AP, McClesky EW, Olivera BM, Thayer SA, Miller $\mathrm{RJ}$, Tsien RW (1988) Dominant role of N-type Ca channels in evoked release of norepinephrine from sympathetic neurons. Science 239:57-61.

Holz GG, Dunlap K, Kream RM (1988) Characterization of electrically-evoked release of substance $P$ from dorsal root ganglion neurons: methods and dihydropyridine sensitivity. J Neurosci 8:463-471.

Holz GG, Kream RM, Spiegel A, Dunlap K (1989) G proteins couple $\alpha$-adrenergic and GABAb receptors to inhibition of peptide secretion from peripheral sensory neurons. J Neurosci 9:657-666.

Ikeda SR, Schofield GG (1989) Somatostatin blocks a calcium current in rat sympathetic ganglion neurones. J Physiol (Lond) 409:221-240.

Jones SW, Jacobs LS (1990) Dihydropyridine actions on calcium currents of frog sympathethic neurons. J Neurosci 10:2261-2267.

Kasai H, Aosaki T (1989) Modulation of Ca-channel current by an adenosine analog mediated by a GTP-binding protein in chick sensory neurons. Pfluegers Arch 414:145-149.

Kasai H, Aosaki T, Fukuda J (1987) Presynaptic Ca-antagonist $\omega$-conotoxin irreversibly blocks N-type Ca-channels in chick sensory neurons. Neurosci Res 4:228-235.

Lee KS, Tsien RW (1982) Reversal of current through calcium channels in dialysed single heart cells. Nature 297:498-501.

Marchetti C, Robello M (1989) Guanosine-5'-O-(3-thiotriphosphate) modified kinetics of voltage-dependent calcium current in chick sensory neurons. Biophys J 56:267-1272.

Marchetti C, Carbone E, Lux HD (1986) Effects of dopamine and noradrenaline on $\mathrm{Ca}$ channels of cultured sensory and sympathetic neurons of chick. Pfluegers Arch 406:104-111.

McClesky EW, Fox AP, Feldman DH, Cruz LJ, Olivera BM, Tsien RW, Yoshikami D (1987) $\omega$-Conotoxin: direct and persistent blockade of specific types of calcium channels in neurons but not muscle. Proc Natl Acad Sci USA 84:4327-4331.

Miller RJ (1987) Multiple calcium channels and neuronal function. Science 235:46-52. 
Nowycky MC, Fox AP, Tsien RW (1985a) Three types of neuronal calcium channel with different calcium agonist sensitivity. Naturc 316:440-443.

Nowycky MC, Fox AP, Tsien RW (1985b) Long-opening mode of gating of neuronal calcium channels and its promotion by the dihydropyridine calcium agonist Bay K 8644. Proc Natl Acad Sci USA 82:2178-2182.

Olivera BM, Gray WR, Zeikus R, McIntosh JM, Varga J, Rivier J, de Santos V, Cruz LJ (1985) Peptide neurotoxins from fish-hunting cone snails. Science 230:1338-1343.

Perney TM, Hirning LD, Leeman SE, Miller RJ (1986) Multiple calcium channels mediate neurotransmitter release from peripheral neurons. Proc Natl Acad Sci USA 83:6656-6659.

Plummer MR, Logothetis DE, Hess P (1989) Elementary properties and pharmacological sensitivities of calcium channels in mammalian peripheral neurons. Neuron 2:1453-1463.

Rane SG, Dunlap K (1990) G protein- and kinase C-mediated regulation of voltage-dependent calcium channels. In: $G$ proteins (Iyengar R, Birnbaumer L, eds), pp 357-381. San Diego: Academic.

Rane SG, Holz GG, Dunlap K (1987) Dihydropyridine inhibition of neuronal calcium channel current and substance $P$ release. Pfluegers Arch 409:361-366.

Regan LJ, Sah DW, Bean BP (1991) Ca channels in rat central and peripheral neurons: high-threshold current resistant to dihydropyridine blockers and $\omega$-conotoxin. Neuron 6:269-280.
Sah DW (1990) Neurotransmitter modulation of calcium current in rat spinal cord neurons. J Neurosci 10:136-141.

Sanguinetti MC, Kass RS (1984) Voltage-dependent block of calcium channel current in the calf cardiac Purkinje fiber by dihydropyridine calcium channel antagonists. Circ Res 55:336-348.

Sanguinetti MC, Krafte DS, Kass RS (1986) Voltage-dependent modulation of $\mathrm{Ca}$ channel current in heart cells by Bay K 8644. J Gen Physiol 88:369-392.

Swandulla D, Armstrong CM (1988) Fast-deactivating Ca channels in chick sensory neurons. J Gen Physiol 92:197-218.

Swandulla D, Carbone E, Lux HD (1991) Do calcium channel classifications account for neuronal calcium channel diversity? Trends Neurosci 14:46-51.

Toselli M, Lang J, Costa T, Lux HD (1989) Direct modulation of voltage-dependent calcium channels by muscarinic activation of a pertussis toxin-sensitive G-protein in hippocampal neurons. Pfluegers Arch 415:255-261.

Tsien RW, Lipscombe D, Madison DV, Bley KR, Fox AP (1988) Multiple types of calcium channels and their selective modulation. Trends Neurosci 11:431-438.

Wanke E, Ferroni A, Malgaroli A, Ambrosini A, Pozzan T, Meldolesi J (1987) Activation of a muscarinic receptor selectively inhibits a rapidly inactivated $\mathrm{Ca}$ current in rat sympathetic neurons. Proc Natl Acad Sci USA 84:4313-4317. 